\title{
UPAYA MENINGKATKAN BELAJAR SISWA MELALUI METODE PEMBELAJARAN KOLABORATIF MATA PELAJARAN IPS PADA SISWA KELAS III SDN BABATAN TAHUN PELAJARAN 2016/2017
}

\author{
Suminah \\ SDN Babatan Gresik \\ suminahminah@gmail.com
}

\begin{abstract}
ABSTRAK
Pembelajaran IPS tidak lagi mengutamakan pada penyerapan melalui pencapaian informasi, tetapi lebih mengutamakan pada pengembangan kemampuan dan pemrosesan informasi. Untuk itu aktivitas peserta didik perlu ditingkatkan melalui latihan-latihan atau tugas IPS dengan bekerja kelompok kecil dan menjelaskan ide-ide kepada orang lain. (Hartoyo, 2000: 24). Tujuan penelitian ini adalah untuk mengetahui peningkatan prestasi belajar siswa setelah diterapkannya Pembelajaran Kolaboratif, serta untuk mengetahui pengaruh motivasi belajar siswa setelah diterapkan Pembelajaran Kolaboratif. Penelitian ini menggunakan penelitian tindakan (action research) sebanyak tiga putaran. Setiap putaran terdiri dari empat tahap yaitu: rancangan, kegiatan dan pengamatan, refleksi, dan refisi. Sasaran penelitian ini adalah siswa kelas III Data yang diperoleh berupa hasil tes formatif, lembar observasi kegiatan belajar mengajar. Dari hasil analisis diperoleh bahwa prestasi belajar siswa mengalami peningkatan dari siklus I sampai siklus III yaitu, siklus I (6NIP. ,00\%), siklus II (76,00\%), siklus III (NIP. NIP. ,00\%). Kesimpulan dari penelitian ini adalah Pembelajaran Kolaboratifdapat berpengaruh positif terhadap motivasi belajar Siswa Kelas III SDN Babatan Kecamatan Balongpanggang Kabupaten Gresik Tahun Pelajaran 2016/2017 serta Media Pembelajaran ini dapat digunakan sebagai salah satu alternatif pembelajaran IPS.
\end{abstract}

Kata Kunci: IPS, Pembelajaran Kolaboratif

\section{ABSTRACT}

IPS learning no longer focuses on absorption through the achievement of information, but rather prioritizes the development of information capability and processing. For that the activities of learners need to be improved through the exercises or tasks of IPS by working small groups and explaining ideas to others. (Hartoyo, 2000: 24). The purpose of this study is to determine the improvement of student achievement after the implementation of Collaborative Learning, and to determine the effect of student learning motivation after applied Collaborative Learning. This research uses action research for three rounds. Each round consists of four stages: design, activity and observation, reflection, and refission. Target of this research is student of class III Data obtained in the form of result of formative test, observation sheet of teaching and learning activity. From the analysis result obtained that the student's learning achievement has increased from cycle I to cycle III that is, cycle I (6NIP., 00\%), cycle II (76,00\%), cycle III (NIP .NIP., $00 \%)$. The conclusion of this study is Collaborative Learning can have a positive effect on the motivation of learning Class III students SDN Babatan Kecamatan Balongpanggang Gresik District Lessons 2016/2017 and Media Learning can be used as an alternative learning IPS.

Keywords: IPS, Collaborative Learning

\section{PENDAHULUAN}

Akhir dari rangkaian proses belajar mengajar adalah tes akhir suatu mata pelajaran yang dilakukan melalui tes formatif, tes akhir cawu, tes akhir semester atau tes ujian kenaikan kelas bagi siswa kelas enam sekolah dasar. Di dalam menghadapi 
tes ujian kenaikan kelas bagi siswa Kelas III SD Negeri BABATAN Kabupaten Gresik Tahun Pelajaran 2016/2017 perlu adanya refreshing terhadap materi ajar yang telah diterima oleh siswa selama mengikuti proses belajar mengajar.

Bagaimanakah caranya agar siswa tidak melupakan materi pelajaran yang telah diterimanya agar siswa nantinya siap menghadapi ujian kenaikan kelas yang siap atau tidak siap harus mereka hadapi. Bagaimanakah membuat suatu materi ajar agar agar tidak terlupakan oleh anak didik. Dalam hal ini guru harus mencari metode untuk mengingatkan segala memori di benak siswa yang telah mereka terima. Guru harus bisa membangkitkan kembali memori itu.

Salah satu metode pengajaran yang bisa membuat anak bisa dan harus mengingat kembali materi pelajaran yang telah mereka terima adalah cara belajar aktif model pembelajaran meninjau ulang kesulitan pada materi pelajaran.

Belajar memerlukan keterlibatan mental dan kerja siswa sendiri. Penjelasan dan pemeragaan semata tidak akan membuahkan hasil belajar yang hanyalah kegiatan belajar aktif.

Agar belajar manjadi aktif, siswa harus mengerjakan banyak sekali tugas. Mereka haru menggunakan otak, mengkaji gagasan, memecahkan masalah, dan menerapkan apa yang mereka pelajari. Belajar aktif harus gesit, menyenangkan, bersemangat dan penuh gairah. Siswa bahkan sering meninggalkan tempat duduk mereka, bergerak leluasa dan berfikir keras (moving about dan thinking aloud).

Tampaknya, perlu adanya perubahan paradigma dalam menelaah proses belajar siswa dan interaksi antara siswa dan guru. Sudah seyogyanyalah kegiatan belajar mengajar juga lebih mempertimbangkan siswa. Siswa bukanlah sebuah botol kosong yang bisa diisi dengan muatan-muatan informasi apa saja yang dianggap perlu oleh guru. Dalam proses belajar mengajar tersebut guru menjadi pemeran utama dalam menciptakan situasi interaktif yang edukatif, yakni intrraksi antara guru dengan siswa, siswa dengan siswa dan dengan sumber pembelajaran dalam menunjang tercapainya tujuan belajar.

IPS sebagai salah satu bidang studi yang memiliki tujuan membekali siswa untuk mengembangkan penalarannya di samping aspek nilai dan moral, banyak memuat materi sosial dan bersifat penerapan sehingga pengetahuan dan informasi yang di terima siswa sebatas produk hapalan dan juga penerapam Sifat materi pelajaran IPS tersebut membawa konsekuensi terhadap proses belajar mengajar yang didominasi oleh pendekatan ekspositoris, terutama guru menggunakan metode ceramah sedangkan siswa kurang terlibat atau 
cenderung pasif. Dalam metode ceramah terjadi dialog imperatif. Padahal, dalam proses belajar mengajar keterlibatan siswa harus secara totalitas, artinya melibatkan pemikiran, penglihatan pendengaran dan psikomotor (keterampilan, salah satunya sambil menulis).

Jadi, dalam proses belajar mengajar, seorang guru harus mengajak siswa untuk mendengarkan, menyajikan media yang dapat dilihat, memberi kesempatan untuk menulis dan mengajukan pertanyaan atau tanggapan sehingga terjadi dialog kreatif yang menunjukkan proses belajar mengajar yang interaktif.

Proses belajar mengajar mempunyai makna dan pengertian yang lebih luas dari pada pengertian mengajar, karena didalamnya tersirat satu kesatuan kegiatan yang tidak terpisahkan antara siswa yang belajar dan guru yang mengajar, yang terjalin dalam bentuk interaksi edukatif.

Dari latar belakang masalah tersebut, maka peneliti merasa terdorong untuk melihat pengaruh pembelajaran terstruktur dan pemberian balikan terhadap prestasi belajar siswa dengan mengambil judul

" Upaya Meningkatkan Belajar Siswa Melalui Metode Pembelajaran Kolaboratif Mata Pelajaran IPS Pada Siswa Kelas III SDN Babatan Tahun Pelajaran 2016/2017"

\section{METODOLOGI PENELITIAN}

Penelitian ini bertempat di Kelas III SD Negeri BABATAN Kabupaten
Gresik Tahun Pelajaran 2016/2017. Penelitian ini dilaksanakan pada bulan Maret semester genap 2016/2017.

Subyek penelitian dalam penelitian ini adalah siswa-siswi Kelas III SD Negeri BABATAN Kabupaten Gresik Tahun Pelajaran 2016/2017.

\section{Rancangan Penelitian}

Penelitian ini menggunakan Karya Tulis IImiah (PTK). Menurut Tim Pelatih Proyek PGSM, PTK adalah suatu bentuk kajian yang bersifat reflektif oleh pelaku tindakan yang dilakukan untuk meningkatkan kemantapan rasional dari tindakan mereka dalam melaksanakan tugas, memperdalam pemahaman terhadap tindakan-tindakan yang dilakukan itu, serta memperbaiki kondisi dimana praktek pembelajaran tersebut dilakukan (Mukhlis, 2000: 3).

Sesuai dengan jenis penelitian yang dipilih, yaitu penelitian tindakan, maka penelitian ini menggunakan model penelitian tindakan dari Kemmis dan Taggart (dalam Sugiarti, 1997: 6), yaitu berbentuk spiral dari sklus yang satu ke siklus yang berikutnya. Setiap siklus meliputi planning (rencana), action (tindakan), observation (pengamatan), dan reflection (refleksi). Langkah pada siklus berikutnya adalah perncanaan yang sudah direvisi, tindakan, pengamatan, dan refleksi. Sebelum masuk pada siklus 1 dilakukan tindakan pendahuluan yang berupa identifikasi permasalahan. Siklus spiral 
dari tahap-tahap Karya Tulis IImiah dapat dilihat pada gambar berikut.

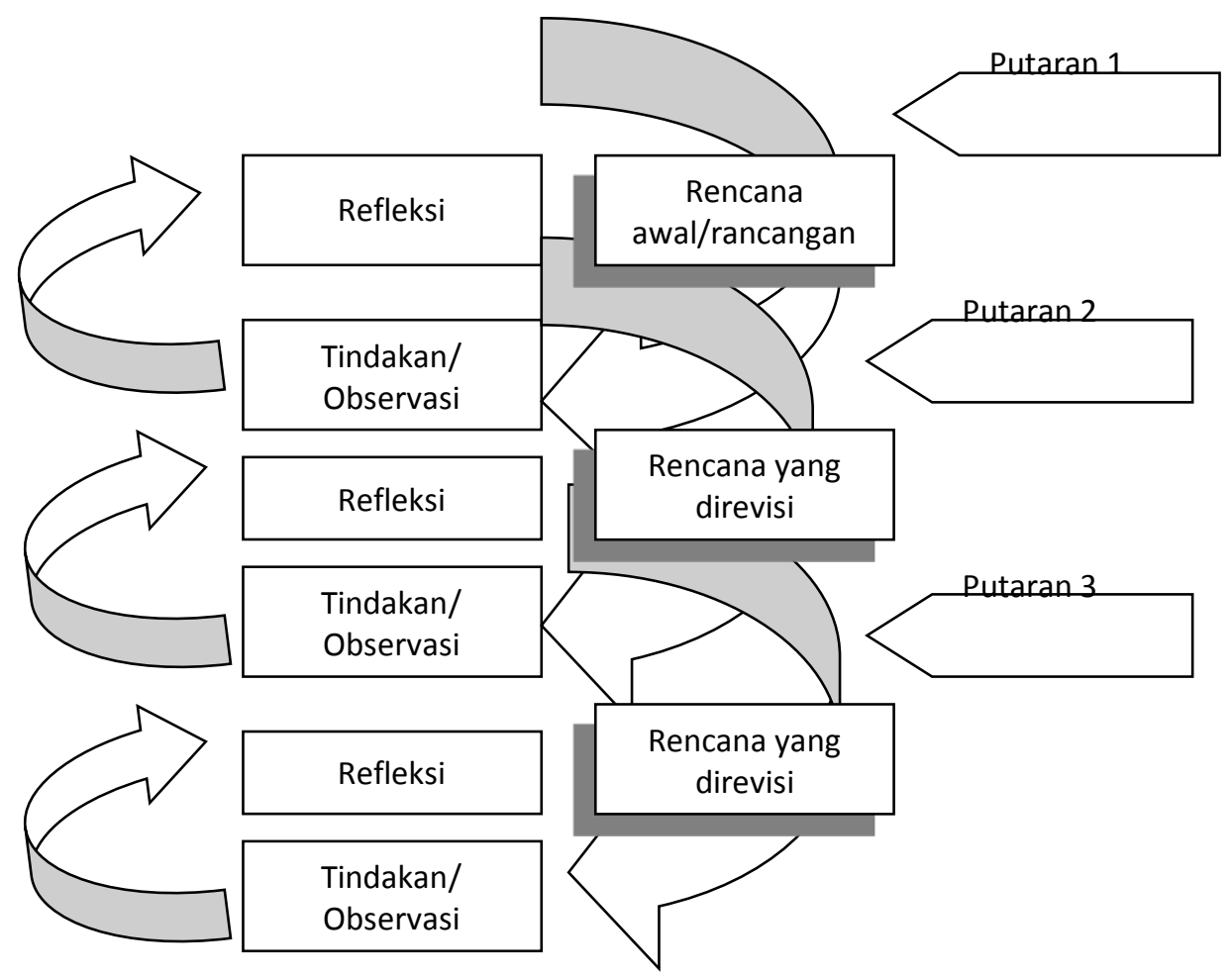

Gambar 1. Alur PTK

Penjelasan alur di atas adalah:

1. Rancangan/rencana awal, sebelum mengadakan penelitian peneliti menyusun rumusan masalah, tujuan dan membuat rencana tindakan, termasuk di dalamnya instrumen penelitian dan perangkat pembelajaran.

2. Kegiatan dan pengamatan, meliputi tindakan yang dilakukan oleh peneliti sebagai upaya membangun pemahaman konsep siswa serta mengamati hasil atau dampak dari diterapkannya metode Kolaboratif

3. Refleksi, peneliti mengkaji, melihat dan mempertimbangkan hasil atau dampak dari tindakan yang dilakukan berdasarkan lembar pengamatan yang diisi oleh pengamat.

4. Rancangan/rencana yang direvisi, berdasarkan hasil refleksi dari pengamat membuat rancangan yang direvisi untuk dilaksanakan pada siklus berikutnya.

Observasi dibagi dalam tiga putaran, yaitu putaran 1, 2 dan 3, dimana masing putaran dikenai perlakuan yang sama (alur kegiatan yang sama) dan membahas satu sub pokok bahasan yang diakhiri dengan tes formatif di akhir masing putaran. Dibuat dalam tiga putaran dimaksudkan untuk memperbaiki sistem pengajaran yang telah dilaksanakan. 


\section{Instrumen Penelitian}

Instrumen yang digunakan dalam penelitian ini terdiri dari:

1. Silabus

Yaitu seperangkat rencana dan pengaturan tentang kegiatan pembelajaran pengelolahan kelas, serta penilaian hasil belajar.

2. Rencana Pelajaran (RP)

Yaitu merupakan perangkat pembelajaran yang digunakan sebagai pedoman guru dalam mengajar dan disusun untuk tiap putaran. Masing-masing RP berisi kompetensi dasar, indikator pencapaian hasil belajar, tujuan pembelajaran khusus, dan kegiatan belajar mengajar.

3. Lembar Kegiatan Siswa

Lembar kegiatan ini yang dipergunakan siswa untuk membantu proses pengumpulan data hasil eksperimen.

4. Tes formatif

Tes ini disusun berdasarkan tujuan pembelajaran yang akan dicapai, digunakan untuk mengukur kemampuan pemahaman konsep matematika pada yang telah dipelajari selama ini. Tes formatif ini diberikan setiap akhir putaran. Bentuk soal yang diberikan adalah pilihan ganda (objektif). Sebelumnya soal-soal ini berjumlah 46 soal yang telah diujicoba, kemudian penulis mengadakan analisis butir soal tes yang telah diuji validitas dan reliabilitas pada tiap soal. Analisis ini digunakan untuk memilih soal yang baik dan memenuhi syarat digunakan untuk mengambil data. Langkah-langkah analisi butir soal adalah sebagai berikut:

a. Validitas Tes

Validitas butir soal atau validitas item digunakan untuk mengetahui tingkat kevalidan masing-masing butir soal. Sehingga dapat ditentukan butir soal yang gagal dan yang diterima. Tingkat kevalidan ini dapat dihitung dengan korelasi Product Moment:

$$
r_{x y}=\frac{N \sum X Y-\left(\sum x\right)\left(\sum Y\right)}{\sqrt{\left\{N \sum X^{2}-\left(\sum x\right)^{2}\right\}\left\{N \sum Y^{2}-\left(\sum Y\right)^{2}\right\}}}
$$

(Arikunto, 2001: 72)

Dengan:

$r_{x y}$ : Koefisien korelasi product moment

$\mathrm{N}$ : Jumlah peserta tes

$\Sigma Y \quad$ : Jumlah skor total

$\Sigma X$ : Jumlah skor butir soal

$\Sigma X^{2}$ : Jumlah kuadrat skor butir soal

$\Sigma X Y$ : Jumlah hasil kali skor butir soal

b. Reliabilitas

Reliabilitas butir soal dalam penelitian ini menggunakan rumus belah dua sebagai berikut:

$$
r_{11}=\frac{2 r_{1 / 21 / 2}}{\left(1+r_{1 / 21 / 2}\right)}
$$

(Arikunto, 20001: 93)

Dengan:

$$
\begin{gathered}
r_{11} \quad \text { Koefisien reliabilatas } \\
\text { yang sudah disesuaikan }
\end{gathered}
$$


$r_{1 / 21 / 2}:$ Korelasi antara skor-skor setiap belahan tes

Kriteria reliabilitas tes jika harga $r_{11}$ dari perhitungan lebih besar dari harga $r$ pada tabel product moment maka tes tersebut reliable.

c. Taraf Kesukaran

Bilangan yang menunjukkan sukar dan mudahnya suatu soal adalah indeks kesukaran. Rumus yang digunakan untuk menentukan taraf kesukaran adalah:

$$
P=\frac{B}{J s} \text { (Arikunto, 2001: 208) }
$$

\section{Dengan:}

$P$ : Indeks kesukaran

B : Banyak siswa yang menjawab soal dengan benar

Js : Jumlah seluruh siswa peserta tes

Kriteria untuk menentukan indeks kesukaran soal adalah sebagai berikut:

- Soal dengan $P=0,000$ sampai 0,300 adalah sukar

- Soal dengan $P=0,301$ sampai 0,700 adalah sedang

- Soal dengan $P=0,701$ sampai 1,000 adalah mudah

d. Daya Pembeda

Daya pembeda soal adalah kemampuan suatu soal untuk membedakan antara siswa yang berkemampuan tinggi dengan siswa yang berkemampuan rendah. Angka yang menunjukkan besarnya daya pembeda desebut indeks diskriminasi. Rumus yang digunakan untuk menghitung indeks diskriminasi adalah sebagai berikut:

$$
\mathrm{D}=\frac{\mathrm{B}_{\mathrm{A}}}{\mathrm{J}_{\mathrm{A}}}-\frac{\mathrm{B}_{\mathrm{B}}}{\mathrm{J}_{\mathrm{B}}}=\mathrm{P}_{\mathrm{A}}-\mathrm{P}_{\mathrm{B}}
$$

(Arikunto, 2001: 211)

Dimana:

D : Indeks diskriminasi

$B_{A}$ : Banyak peserta kelompok atas yang menjawab dengan benar

$\mathrm{B}_{\mathrm{B}}$ : Banyak peserta kelompok bawah yang menjawab dengan benar

$\mathrm{J}_{\mathrm{A}}$ : Jumlah peserta kelompok atas

$J_{B}$ : Jumlah peserta kelompok bawah

$\mathrm{P}_{\mathrm{A}}$ : Proporsi peserta kelompok atas yang menjawab benar.

$\mathrm{P}_{\mathrm{B}}$ : Proporsi peserta kelompok bawah yang menjawab benar

Kriteria yang digunakan untuk menentukan daya pembeda butir soal sebagai berikut:

- Soal dengan $D=0,000$ sampai 0,200 adalah jelek

- Soal dengan $D=0,201$ sampai 0,400 adalah cukup

- Soal dengan $D=0,401$ sampai 0,700 adalah baik

- Soal dengan $D=0,701$ sampai 1,000 adalah sangat baik 


\section{Metode Pengumpulan Data}

Data-data yang diperlukan dalam penelitian ini diperoleh melalui observasi pengolahan metode pembelajaran Kolaboratif pada materi pelajaran, dan tes formatif.

\section{E. Teknik Analisis Data}

Untuk mengetahui keefektivan suatu metode dalam kegiatan pembelajaran perlu diadakan analisa data. Pada penelitian ini menggunakan teknik analisis deskriptif kualitatif, yaitu suatu metode penelitian yang bersifat menggambarkan kenyataan atau fakta sesuai dengan data yang diperoleh dengan tujuan untuk mengetahui prestasi belajar yang dicapai siswa juga untuk memperoleh respon siswa terhadap kegiatan pembelajaran serta aktivitas siswa selama proses pembelajaran.

Untuk mengalisis tingkat keberhasilan atau persentase keberhasilan siswa setelah proses belajar mengajar setiap putarannya dilakukan dengan cara memberikan evaluasi berupa soal tes tertulis pada setiap akhir putaran.

Analisis ini dihitung dengan menggunakan statistik sederhana yaitu:

1. Untuk menilai ulangan atau tes formatif

$$
\text { Peneliti melakukan }
$$
penjumlahan nilai yang diperoleh siswa, yang selanjutnya dibagi dengan jumlah siswa yang ada di kelas tersebut sehingga diperoleh rata-rata tes formatif dapat dirumuskan:

$$
\bar{x}=\frac{\sum x}{\sum N}
$$

Dengan

$\overline{\mathrm{X}}=$ Nilai rata-rata

$\Sigma \mathrm{X}=$ Jumlah semua nilai siswa

$\Sigma \mathrm{N}=$ Jumlah siswa

2. Untuk ketuntasan belajar

Ada dua kategori ketuntasan belajar yaitu secara perorangan dan secara klasikal. Berdasarkan petunju pelaksanaan belajar mengajar kurikulum 1994 (Depdikbud, 1994), yaitu seorang siswa telah tuntas belajar bila telah mencapai skor $65 \%$ atau nilai 65 , dan kelas disebut tuntas belajar bila di kelas tersebut terdapat $85 \%$ yang telah mencapai daya serap lebih dari atau sama dengan $65 \%$. Untuk menghitung persentase ketuntasan belajar digunakan rumus sebagai berikut:

$$
\mathrm{P}=\frac{\sum \text { Siswa yang tuntas belajar }}{\sum \text { Siswa }} \times 100 \%
$$

\section{HASIL DAN PEMBAHASAN}

\section{Analisis Data Penelitian Persiklus}

1. Siklus I

a. Tahap Perencanaan

Pada tahap ini peneliti mempersiapkan perangkat pembelajaran yang terdiri dari rencana pelajaran 1 , soal tes formatif 1 dan alat-alat pengajaran yang mendukung. 
b. Tahap Kegiatan dan guru. Adapun proses belajar Pelaksanaan

Pelaksanaan kegiatan mengajar mengacu pada rencana pelajaran yang telah belajar mengajar untuk siklus I dilaksanakan pada tanggal 1 dipersiapkan.

Pengamatan Maret 2017 di Kelas III dengan (observasi) dilaksanakan jumlah siswa 35 siswa. Dalam bersamaan dengan pelaksaaan hal ini peneliti bertindak sebagai belajar mengajar.

Tabel 1. Nilai Tes Formatif Pada Siklus I

\begin{tabular}{|c|c|c|c|c|c|c|c|}
\hline \multirow{2}{*}{$\begin{array}{l}\text { No. } \\
\text { Urut }\end{array}$} & \multirow{2}{*}{ Nilai } & \multicolumn{2}{|c|}{ Keterangan } & \multirow{2}{*}{$\begin{array}{l}\text { No. } \\
\text { Urut }\end{array}$} & \multirow{2}{*}{ Nilai } & \multicolumn{2}{|c|}{ Keterangan } \\
\hline & & Tuntas & Tidak Tuntas & & & Tuntas & Tidak Tuntas \\
\hline 1 & 70 & $\mathrm{~V}$ & & 19 & 80 & V & \\
\hline 2 & 60 & & $\mathrm{v}$ & 20 & 70 & $\mathrm{~V}$ & \\
\hline 3 & 70 & $\mathrm{v}$ & & 21 & 40 & & $\mathrm{v}$ \\
\hline 4 & 80 & $\mathrm{~V}$ & & 22 & 80 & $\mathrm{~V}$ & \\
\hline 5 & 80 & $\mathrm{~V}$ & & 23 & 60 & & $\mathrm{v}$ \\
\hline 6 & 40 & & $\mathrm{v}$ & 24 & 50 & & $\mathrm{~V}$ \\
\hline 7 & 70 & $\mathrm{v}$ & & 25 & 80 & $\mathrm{~V}$ & \\
\hline 8 & 50 & & $\mathrm{v}$ & 26 & 60 & & $v$ \\
\hline 9 & 80 & $\mathrm{~V}$ & & 27 & 80 & $\mathrm{v}$ & \\
\hline 10 & 40 & & $\mathrm{v}$ & 28 & 70 & $\mathrm{~V}$ & \\
\hline 11 & 70 & $\mathrm{v}$ & & 29 & 80 & $\mathrm{~V}$ & \\
\hline 12 & 50 & $\mathrm{~V}$ & & 30 & 80 & $\mathrm{~V}$ & \\
\hline 13 & 70 & $\mathrm{v}$ & & 31 & 80 & $\mathrm{v}$ & \\
\hline 14 & 60 & & $\sqrt{ }$ & 32 & 70 & $\mathrm{~V}$ & \\
\hline 15 & 70 & v & & 33 & 40 & & v \\
\hline 16 & 80 & $\mathrm{~V}$ & & 34 & 80 & $\mathrm{v}$ & \\
\hline 17 & 80 & $\sqrt{ }$ & & 35 & 60 & & $\mathrm{~V}$ \\
\hline 18 & 60 & & $\mathrm{~V}$ & Jumlah & 1160 & 11 & 6 \\
\hline Jumlah & 1180 & 12 & 6 & (Jumian & 1100 & 11 & 0 \\
\hline Jumlah $\subseteq$ & & & $: 2330$ & & & & \\
\hline Jumlah $\subseteq$ & or Maks & nal Ideal & $: 3500$ & & & & \\
\hline \% Skor T & capai & & $: 66,85$ & & & & \\
\hline Jumlah s & wa yan & elum tur & as $: 12$ & & & & \\
\hline Klasikal & & & : Belum tı & tas & & & \\
\hline
\end{tabular}

Tabel 2. Distribusi Hasil Tes Formatif Siswa pada Siklus I

\begin{tabular}{|c|l|c|}
\hline No & \multicolumn{1}{|c|}{ Uraian } & Hasil Siklus I \\
\hline 1 & Nilai rata-rata tes formatif & 66,85 \\
2 & Jumlah siswa yang tuntas belajar & 23 \\
3 & Persentase ketuntasan belajar & 65,71 \\
\hline
\end{tabular}

Dari tabel di atas dapat dijelaskan bahwa dengan menerapkan metode belajar
Kolaboratif pada materi pelajaran diperoleh nilai ratarata prestasi belajar siswa 
adalah 66,80 dan ketuntasan belajar mencapai $64,00 \%$ atau ada 16 siswa dari 35 siswa sudah tuntas belajar. Hasil tersebut menunjukkan bahwa pada siklus pertama secara klasikal siswa belum tuntas belajar, karena siswa yang memperoleh nilai $\geq 65$ hanya sebesar $65,71 \%$ lebih kecil dari persentase ketuntasan yang dikehendaki yaitu sebesar $85 \%$. Hal ini disebabkan karena siswa banyak yang lupa dengan materi pelajaran yang telah diajarkan selama hampir satu semester ini.

2. Siklus II

a. Tahap perencanaan

Pada tahap inipeneliti mempersiapkan perangkat pembelajaran yang terdiri dari rencana pelajaran 2 , soal tes formatif II dan alat-alat pengajaran yang mendukung.

b. Tahap kegiatan dan pelaksanaan Pelaksanaan kegiatan belajar mengajar untuk siklus II dilaksanakan pada tanggal 3 Maret 2017 di Kelas III dengan jumlah siswa 35 siswa. Dalam hal ini peneliti bertindak sebagai guru. Adapun proses belajar mengajar mengacu pada rencana pelajaran dengan memperhatikan revisi pada siklus I, sehingga keslah atau kekurangan pada siklus I tidak terulang lagi pada siklus II. Pengamatan (observasi) dilaksanakan bersamaan dengan pelaksanaan belajar mengajar.

Tabel 3. Nilai Tes Formatif Pada Siklus II

\begin{tabular}{|c|c|c|c|c|c|c|c|}
\hline \multirow{2}{*}{$\begin{array}{l}\text { No. } \\
\text { Urut }\end{array}$} & \multirow{2}{*}{ Nilai } & \multicolumn{2}{|c|}{ Keterangan } & \multirow{2}{*}{$\begin{array}{l}\text { No. } \\
\text { Urut }\end{array}$} & \multirow{2}{*}{ Nilai } & \multicolumn{2}{|c|}{ Keterangan } \\
\hline & & Tuntas & Tidak Tuntas & & & Tuntas & Tidak Tuntas \\
\hline 1 & 80 & $\mathrm{~V}$ & & 19 & 70 & $\mathrm{~V}$ & \\
\hline 2 & 70 & $\mathrm{~V}$ & & 20 & 80 & $\mathrm{~V}$ & \\
\hline 3 & 60 & & $\mathrm{v}$ & 21 & 70 & $\mathrm{~V}$ & \\
\hline 4 & 70 & $\mathrm{~V}$ & & 22 & 50 & & $\mathrm{v}$ \\
\hline 5 & 60 & & $\mathrm{~V}$ & 23 & 70 & V & \\
\hline 6 & 70 & $\mathrm{~V}$ & & 24 & 70 & $\mathrm{v}$ & \\
\hline 7 & 70 & $\mathrm{v}$ & & 25 & 60 & $v$ & \\
\hline 8 & 80 & $\mathrm{~V}$ & & 26 & 50 & & $\mathrm{v}$ \\
\hline 9 & 70 & $\mathrm{~V}$ & & 27 & 70 & v & \\
\hline 10 & 70 & $\mathrm{v}$ & & 28 & 80 & $v$ & \\
\hline 11 & 50 & & $\mathrm{~V}$ & 29 & 90 & $v$ & \\
\hline 12 & 50 & & $\mathrm{v}$ & 30 & 80 & v & \\
\hline 13 & 70 & $\mathrm{~V}$ & & 31 & 70 & $\mathrm{~V}$ & \\
\hline 14 & 80 & $\mathrm{~V}$ & & 32 & 80 & $\mathrm{v}$ & \\
\hline 15 & 70 & $\mathrm{v}$ & & 33 & 70 & $v$ & \\
\hline 16 & 60 & & $\mathrm{v}$ & 34 & 50 & & $\mathrm{v}$ \\
\hline
\end{tabular}




\begin{tabular}{|c|c|c|c|c|c|c|c|c|}
\hline \multirow{2}{*}{$\begin{array}{l}\text { No. } \\
\text { Urut }\end{array}$} & \multirow{2}{*}{ Nilai } & \multicolumn{3}{|c|}{ Keterangan } & \multirow{2}{*}{$\begin{array}{l}\text { No. } \\
\text { Urut }\end{array}$} & \multirow{2}{*}{ Nilai } & \multicolumn{2}{|c|}{ Keterangan } \\
\hline & & Tuntas & Tid & ak Tuntas & & & Tuntas & Tidak Tuntas \\
\hline 17 & 70 & $\mathrm{~V}$ & & & 35 & 70 & $\mathrm{~V}$ & \\
\hline 18 & 70 & $\sqrt{ }$ & & & Jumlah & 1180 & 14 & 3 \\
\hline Jumlah & 1220 & 13 & & 5 & & & & \\
\hline \multicolumn{9}{|c|}{ Jumlah Skor $\quad: 2400$} \\
\hline \multirow{2}{*}{\multicolumn{4}{|c|}{$\begin{array}{l}\text { Jumlah Skor Maksimal Ideal } \\
\% \text { Skor Tercapai }\end{array}$}} & : 3500 & & & & \\
\hline & & & & $: 68,57$ & & & & \\
\hline \multicolumn{4}{|c|}{ Jumlah siswa yang tuntas } & $: 27$ & & & & \\
\hline \multicolumn{4}{|c|}{ Jumlah siswa yang belum tuntas } & $: 8$ & & & & \\
\hline \multicolumn{4}{|c|}{ Klasikal } & : Belum & untas & & & \\
\hline
\end{tabular}

Tabel 4. Distribusi Hasil Tes Formatif Siswa pada Siklus II

\begin{tabular}{|c|l|c|}
\hline No & \multicolumn{1}{|c|}{ Uraian } & Hasil Siklus II \\
\hline 1 & Nilai rata-rata tes formatif & 68,57 \\
2 & Jumlah siswa yang tuntas belajar & 27 \\
3 & Persentase ketuntasan belajar & 77,14 \\
\hline
\end{tabular}

Dari tabel di atas diperoleh nilai rata-rata prestasi belajar siswa adalah 68,57\% dan ketuntasan belajar mencapai 77,14\% atau ada 27 siswa dari 35 siswa sudah tuntas belajar. Hasil ini menunjukkan bahwa pada siklus II ini ketuntasan belajar secara klasikal telah mengalami peningkatan sedikit lebih baik dari siklus I. Adanya peningkatan hasil belajar siswa ini karena siswa-siswa telah mulai mengulang pelajaran yang sudah diterimanya selama ini sehingga para siswa sebagian sudah mengingat meteri yang telah diajarkan oleh guru.

3. Siklus III

a. Tahap Perencanaan

Pada tahap ini peneliti mempersiapkan perangkat pembelajaran yang terdiri dari rencana pelajaran 3 , soal tes formatif 3 dan alat-alat pengajaran yang mendukung.

b. Tahap kegiatan dan pengamatan

Pelaksanaan kegiatan belajar mengajar untuk siklus III dilaksanakan pada tanggal 4 Maret 2017 di Kelas III dengan jumlah siswa 35 siswa. Dalam hal ini peneliti bertindak sebagai guru. Adapun proses belajar mengajar mengacu pada rencana pelajaran dengan memperhatikan revisi pada siklus II, sehingga kesalahan atau kekurangan pada siklus II tidak terulang laig pada siklus III. Pengamatan (observasi) dilaksanakan bersamaan dengan pelaksanaan belajar mengajar. 
Tabel 5. Nilai Tes Formatif Pada Siklus III

\begin{tabular}{|c|c|c|c|c|c|c|c|}
\hline \multirow{2}{*}{$\begin{array}{l}\text { No. } \\
\text { Urut }\end{array}$} & \multirow{2}{*}{ Nilai } & \multicolumn{2}{|c|}{ Keterangan } & \multirow{2}{*}{$\begin{array}{l}\text { No. } \\
\text { Urut }\end{array}$} & \multirow{2}{*}{ Nilai } & \multicolumn{2}{|c|}{ Keterangan } \\
\hline & & Tuntas & Tidak Tuntas & & & Tuntas & Tidak Tuntas \\
\hline 1 & 90 & $\mathrm{~V}$ & & 19 & 50 & & $\mathrm{~V}$ \\
\hline 2 & 70 & $\mathrm{v}$ & & 20 & 80 & $\mathrm{v}$ & \\
\hline 3 & 70 & 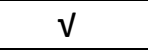 & & 21 & 80 & $\mathrm{~V}$ & \\
\hline 4 & 70 & $\sqrt{ }$ & & 22 & 70 & $v$ & \\
\hline 5 & 80 & $\sqrt{ }$ & & 23 & 80 & $\checkmark$ & \\
\hline 6 & 70 & V & & 24 & 80 & $v$ & \\
\hline 7 & 60 & & 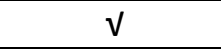 & 25 & 70 & $v$ & \\
\hline 8 & 80 & 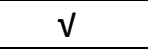 & & 26 & 80 & 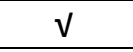 & \\
\hline 9 & 70 & $\mathrm{~V}$ & & 27 & 60 & & v \\
\hline 10 & 90 & $\mathrm{~V}$ & & 28 & 80 & $\mathrm{v}$ & \\
\hline 11 & 70 & $\mathrm{~V}$ & & 29 & 80 & $v$ & \\
\hline 12 & 70 & $\mathrm{~V}$ & & 30 & 90 & $\mathrm{~V}$ & \\
\hline 13 & 90 & $\mathrm{~V}$ & & 31 & 50 & & $\mathrm{~V}$ \\
\hline 14 & 90 & $\sqrt{ }$ & & 32 & 80 & $\mathrm{v}$ & \\
\hline 15 & 70 & $\mathrm{v}$ & & 33 & 80 & $\mathrm{v}$ & \\
\hline 16 & 70 & V & & 34 & 70 & $v$ & \\
\hline 17 & 70 & 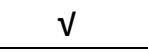 & & 35 & 80 & $v$ & \\
\hline 18 & 80 & $\mathrm{~V}$ & & Jumlah & 1260 & 14 & 3 \\
\hline Jumlah & 1360 & 17 & 1 & & & & \\
\hline \multicolumn{8}{|c|}{ Jumlah Skor $\quad: 2620$} \\
\hline \multirow{2}{*}{\multicolumn{3}{|c|}{$\begin{array}{l}\text { Jumlah Skor Maksimal Ideal } \\
\text { \% Skor Tercapai }\end{array}$}} & : 3500 & & & & \\
\hline & & & : 74,85 & & & & \\
\hline \multicolumn{3}{|c|}{ Jumlah siswa yang tuntas } & $: 31$ & & & & \\
\hline \multicolumn{3}{|c|}{ Jumlah siswa yang belum tuntas } & $:: 4$ & & & & \\
\hline \multicolumn{3}{|c|}{ Klasikal } & : Tuntas & & & & \\
\hline
\end{tabular}

Tabel 6. Distribusi Hasil Tes Formatif Siswa pada Siklus III

\begin{tabular}{|c|c|c|}
\hline No & Uraian & Hasil Siklus III \\
\hline 1 & Nilai rata-rata tes formatif & 74,85 \\
2 & Jumlah siswa yang tuntas belajar & 31 \\
3 & Persentase ketuntasan belajar & 88,57 \\
\hline
\end{tabular}

Berdasarkan tabel diatas diperoleh nilai rata-rata tes formatif sebesar 74,85 dan dari 35 siswa yang telah tuntas sebanyak 31 siswa dan 4 siswa belum mencapai ketuntasan belajar. Maka secara klasikal ketuntasan belajar yang telah tercapai sebesar $88,57 \%$ (termasuk kategori tuntas).
Hasil pada siklus III ini mengalami peningkatan lebih baik dari siklus II. Adanya peningkatan hasil belajar pada siklus III ini dipengaruhi oleh adanya usaha siswa untuk mempelajari kembali materi ajar yang telah disampaikan oleh guru. Disamping itu siswa juga merasa belajar mengulang ini 
adalah juga sebagai persiapan untuk menghadapi ujian kenaikan kelas yang sudah dekat waktunya.

c. Refleksi

Pada tahap ini akah dikaji apa yang telah terlaksana dengan baik maupun yang masih kurang baik dalam proses belajar mengajar dengan penerapan metode belajar Kolaboratif pada materi pelajaran. Dari data-data yang telah diperoleh dapat duraikan sebagai berikut:

1) Selama proses belajar mengajar guru telah melaksanakan semua pembelajaran dengan baik. Meskipun ada beberapa aspek yang belum sempurna, tetapi persentase pelaksanaannya untuk masing-masing aspek cukup besar.

2) Berdasarkan data hasil pengamatan diketahui bahwa siswa aktif selama proses belajar berlangsung.

3) Kekurangan pada siklus-siklus sebelumnya sudah mengalami perbaikan dan peningkatan sehingga menjadi lebih baik.

4) Hasil belajar siswa pada siklus III mencapai ketuntasan.

d. Revisi Pelaksanaan

Pada siklus III guru telah menerapkan metode belajar

\begin{abstract}
Kolaboratif pada materi pelajaran dengan baik dan dilihat dari aktivitas siswa serta hasil belajar siswa pelaksanaan proses belajar mengajar sudah berjalan dengan baik. Maka tidak diperlukan revisi terlalu banyak, tetapi yang perlu diperhatikan untuk tindakah selanjutnya adalah memaksimalkan dan mempertahankan apa yang telah ada dengan tujuan agar pada pelaksanaan proses belajar mengajar selanjutnya penerapan metode belajar Kolaboratif pada materi pelajaran dapat meningkatkan proses belajar mengajar sehingga tujuan pembelajaran dapat tercapai.
\end{abstract}

\section{Pembahasan}

1. Ketuntasan Hasil belajar Siswa

Melalui hasil peneilitian ini menunjukkan bahwa metode belajar Kolaboratif pada materi pelajaran memiliki dampak positif dalam meningkatkan prestasi belajar siswa. Hal ini dapat dilihat dari semakin mantapnya pemahaman siswa terhadap materi yang disampaikan guru untuk menghadapi ujian kenaikan kelas (ketuntasan belajar meningkat dari sklus I, II, dan III) yaitu masingmasing 65,71\%, 71,14\%, dan $88,57 \%$. Pada siklus III ketuntasan belajar siswa secara klasikal telah tercapai. 
2. Kemampuan Guru dalam Mengelola Pembelajaran

Berdasarkan analisis data, diperoleh aktivitas siswa dalam proses metode belajar Kolaboratif pada materi pelajaran dalam setiap siklus mengalami peningkatan. Hal ini berdampak positif terhadap prestasi belajar siswa yaitu dapat ditunjukkan dengan meningkatnya nilai rata-rata siswa pada setiap siklus yang terus mengalami peningkatan.

3. Aktivitas Guru dan Siswa Dalam Pembelajaran

Berdasarkan analisis data, diperoleh aktivitas siswa dalam proses pembelajaran matematika dengan metode belajar Kolaboratif pada materi pelajaran yang paling dominan adalah bekerja dengan menggunakan alat/media, mendengarkan/memperhatikan penjelasan guru, dan diskusi antar siswa/antara siswa dengan guru. Jadi dapat dikatakan bahwa aktivitas isiwa dapat dikategorikan aktif.

\section{KESIMPULAN}

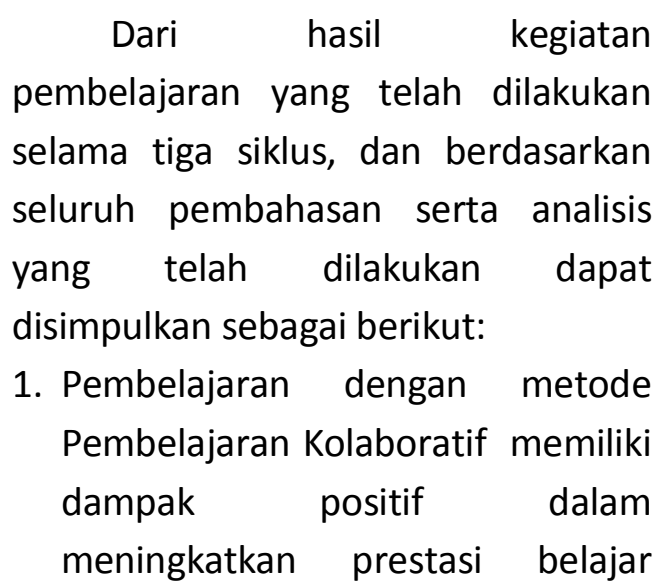

siswa yang ditandai dengan peningkatan ketuntasan belajar siswa dalam setiap siklus, yaitu siklus I $(65,71 \%)$, siklus II $(77,14 \%)$, siklus III $(88,57 \%)$.

2. Penerapan metode Pembelajaran Kolaboratif mempunyai pengaruh positif, yaitu dapat meningkatkan motivasi belajar siswa yang ditunjukan dengan rata-rata jawaban siswa yang menyatakan bahwa siswa tertarik dan berminat dengan metode Pembelajaran Kolaboratif sehingga mereka menjadi termotivasi untuk belajar.

4. Penerapan metode Pembelajaran dapat meningkatkan preatasi siswa Kelas III SD Negeri BABATAN Kabupaten Gresik Tahun Pelajaran 2016/2017

\section{DAFTAR PUSTAKA}

Ali, Muhammad. 1996. Guru Dalam Proses Belajar Mengajar. Bandung: Sinar Baru Algesindon. Arikunto, Suharsimi. 1989. Penilaian Program Pendidikan. Proyek Pengembangan LPTK Depdikbud. Dirjen Dikti.

Arikunto, Suharsimi. 1993. Manajemen Mengajar Secara Manusiawi. Jakarta: Rineksa Cipta.

Arikunto, Suharsimi. 1999. Prosedur Penelitian Suatu Pendekatan Praktek. Jakarta: Rineksa Cipta.

Arikunto, Suharsimi. 2001. DasarDasar Evaluasi Pendidikan. Jakarta: Bumi Margono. 1997. Metodologi

Penelitian 
Pendidikan. Jakarta. Rineksa Cipta.

Mursell, James ( - ). Succesfull Teaching (terjemahan). Bandung: Jemmars.

Ngalim, Purwanto M. 1990. Psikologi Pendidikan. Bandung: PT. Remaja Rosdakarya.

Nur, Moh. 2001. Pemotivasian Siswa untuk Belajar. Surabaya. University Press. Universitas Negeri Surabaya.

Poerwodarminto. 1991. Kamus Umum Bahasa Indonesia. Jakarta: Bina IImu.

Rustiyah, N.K. 1991. Strategi Belajar Mengajar. Jakarta: Bina Aksara.

Sardiman, A.M. 1996. Interaksi dan Motivasi Belajar Mengajar. Jakarta: Bina Aksara.

Slameto, 1988. Evaluasi Pendidikan. Jakarta: Bina Aksara.

Soekamto, Toeti. 1997. Teori Belajar dan Model Pembelajaran. Jakarta: PAU-PPAI, Universitas Terbuka.

Suprayekti. 2008. Pembaharuan Pembelajaran di SD. Jakarta: Universitas Terbuka. 